\title{
In house colorimetric reverse hybridisation assay for detection of the mutation most frequently associated with resistance to isoniazid in Mycobacterium tuberculosis
}

\author{
Mirela Verza ${ }^{1,2}$, Raquel de Abreu Maschmannn, ${ }^{1,2}$, Márcia Susana Nunes Silva ${ }^{1,3}$, \\ Elis Regina Dalla Costa ${ }^{1,4}$, Marta Osório Ribeiro', Franciele Rosso, ${ }^{1,2}$, Philip Noel Suffys ${ }^{5}$, \\ Enrico Tortoli ${ }^{6}$, Fiorella Marcelli ${ }^{6}$, Arnaldo Zaha $^{2}$, Maria Lucia Rosa Rossetti ${ }^{1,3 /+}$
'Centro de Desenvolvimento Científico e Tecnológico, Fundação Estadual de Produção e Pesquisa em Saúde, Av. Ipiranga 5400, 90610-000 Porto Alegre, RS, Brasil ²Programa de Pós-Graduação em Biologia Celular e Molecular, Centro de Biotecnologia, Universidade Federal do Rio Grande do Sul, Porto Alegre, RS, Brasil ${ }^{3}$ Universidade Luterana do Brasil, Canoas, RS, Brasil ${ }^{4}$ Universidade Federal do Rio de Janeiro, Rio de Janeiro, RJ, Brasil ${ }^{5}$ Instituto Oswaldo Cruz-Fiocruz, Rio de Janeiro, RJ, Brasil ${ }^{6}$ Centro Regionale di Riferimento per i Micobatteri, Ospedale di Careggi, Firenze, Italy

Mutations in the $\mathrm{kat} G$ gene have been identified and correlated with isoniazid (INH) resistance in Mycobacterium tuberculosis isolates. The mutation $A G C \rightarrow A C C$ (Ser $\rightarrow T h r)$ at kat $G 315$ has been reported to be the most frequent and is associated with transmission and multidrug resistance. Rapid detection of this mutation could therefore improve the choice of an adequate anti-tuberculosis regimen, the epidemiological monitoring of INH resistance and, possibly, the tracking of transmission of resistant strains. An in house reverse hybridisation assay was designed in our laboratory and evaluated with 180 isolates of M. tuberculosis. It could successfully characterise the katG315 mutation in $100 \%$ of the samples as compared to DNA sequencing. The test is efficient and is a promising alternative for the rapid identification of INH resistance in regions with a high prevalence of katG315 mutants.

Key words: drug resistance - isoniazid - kat G315 - reverse hybridization assay - tuberculosis

Tuberculosis (TB) is the only infectious disease that has been considered a global emergency by the World Health Organization as one third of the world's population is latently infected with Mycobacterium tuberculosis (WHO 2008). The emergence and spread of multidrugresistant (MDR) strains of $M$. tuberculosis are serious threats to the control of TB and represent an increasing public health problem. Patients infected with MDR strains, namely those resistant to at least rifampicin (RIF) and isoniazid (INH), are difficult to cure and likely to remain as sources of infection for a longer period than patients with drug-susceptible strains (Zumla \& Grange 2001). The recently observed spread of extensively drugresistant TB, which is defined as MDR-TB with additional resistance to a fluoroquinolone and a second-line injectable drug, is often incurable (WHO 2008).

The early identification of resistant strains is essential for efficient treatment and control of MDR-TB. Faster application of effective chemotherapy also prevents further spreading of drug-resistant isolates (Parsons et al. 2004).

INH is one of the most effective and specific antibiotics available for the treatment of TB and is also widely used to treat latent M. tuberculosis infections (Espinal

Financial support: CNPq, FINEP, FEPPS

+ Corresponding author: mrossett@terra.com.br

Received 19 December 2008

Accepted 26 June 2009 et al. 2001). This antibiotic is a prodrug that requires activation by the catalase-peroxidase enzyme encoded by the kat $\mathrm{G}$ gene (Hazbon et al. 2006). Activated drug appears to disrupt the synthesis of essential cell wall mycolic acids (Rawat et al. 2003). In the majority of isolates, resistance to INH is mainly achieved through mutations in the kat $\mathrm{G}$ gene and in the inh $\mathrm{A}$ promoter region. Mutations in other genes, such as $\operatorname{ahpC}$ and $n d h$, have been implicated in INH resistance, but their roles have not yet been proven (Hazbon et al. 2006). In various studies, the frequency of INH-resistant strains containing a mutation in codon 315 of the kat $\mathrm{G}$ gene ranged from 50-100\% (Musser et al. 1996, van Soolingen et al. 2000, Silva et al. 2003, Hillemann et al. 2005, Zhang et al. 2005, van Doorn et al. 2006, Dalla Costa et al. 2009). In most cases, one amino acid substitution at codon $315(\mathrm{AGC} \rightarrow \mathrm{ACC} / \mathrm{Ser} \rightarrow \mathrm{Thr})$ was reported to be the most frequent (Mdluli et al. 1996, Musser et al. 1996, van Soolingen et al. 2000, Abate et al. 2001, van Doorn et al. 2001, Mokrousov et al. 2002, Silva et al. 2003, Zakerbostanabad et al. 2008, Dalla Costa et al. 2009). Mutations in katG315 may be favoured because mutations at this location appear to decrease INH activation without abolishing catalase-peroxidase activity, a potential virulence factor (Saint-Joanis et al. 1999, Pym et al. 2002, Wei et al. 2003, Kapetanaki et al. 2005). The kat $\mathrm{G} 315$ mutation is associated with the development and transmission of MDR-TB, whereas other INH resistance-conferring mutations, such as inh $\mathrm{A}-15 \mathrm{C} \rightarrow \mathrm{T}$, are not (van Soolingen et al. 2000, Hazbon et al. 2006, van Doorn et al. 2006). 
Drug susceptibility testing by conventional methods takes more than four weeks. Generally, DNA sequencingbased approaches are considered the reference assays for the detection of mutations, but have often been found to be too cumbersome for routine use. Commercial molecular hybridisation tests for the detection of resistance to INH, such as GenoType MTBDR (Hain Lifescience, Nehren, Germany), are sensitive and specific, but the high cost and need for validation hamper the widespread application in geographic areas where it is most urgently needed (Makinen et al. 2006).

We therefore developed a molecular assay based on reverse hybridisation (RHA) and colorimetric detection for the characterisation of kat $\mathrm{G} 315$ in $M$. tuberculosis. The results of this procedure were compared to data obtained by DNA sequencing. Additionally, some of the DNA was also analyzed with the GenoType MTBDR commercial test.

\section{MATERIALS AND METHODS}

M. tuberculosis isolates - The RHA was standardised with DNA of $M$. tuberculosis extracted from the culture collection of the Laboratório Central do Rio Grande do Sul (Brazil). The assay was performed with a total of 180 DNA samples previously sequenced for the kat $\mathrm{G}$ gene: 60 DNA samples contain a mutation in kat $\mathrm{G} 315$ ( 58 with the mutation $\mathrm{AGC} \rightarrow \mathrm{ACC}$ and 2 with the mutation $\mathrm{AGC} \rightarrow \mathrm{AAC}$ ); 119 samples have no mutation in this codon; one sample contains the mix AGC/ACC. The $M$. tuberculosis reference strain $\mathrm{H} 37 \mathrm{Rv}$ was used as a wildtype control (ATCC27294).

Extraction of nucleic acids - Nucleic acids were extracted from $M$. tuberculosis cultures using the CTAB method described by van Soolingen et al. (1994).

DNA sequencing of the kat G gene - A 232 bp fragment of kat $\mathrm{G}$ was amplified using the primers katG1 (CATGAACGACGTCGAAACAG) and katG2 (CGA GGAAACTGTTGTCCCAT) as described by Silva et al. (2003). Amplifications were carried out in a thermocycler Mini-Cycler-Hot Bonnet PTC-150 (MJ Research) as follows: $94^{\circ} \mathrm{C}$ for $2 \mathrm{~min}, 55^{\circ} \mathrm{C}$ for $1 \mathrm{~min}$ and $72^{\circ} \mathrm{C}$ for $2 \mathrm{~min}$ for 30 cycles. Amplification products were analysed by electrophoresis in $1.5 \%$ agarose gels. PCR products were purified with the polyethylene glycol method (http://pubmlst.org/neisseria/mlst-info/nmeningitidis/pcr.shtml). Sequencing was performed using the Big Dye ${ }^{\circledR}$ Terminator Cycle Sequencing Kit and AmpliTaq DNA polymerase (Applied Biosystems, Foster City, CA, USA) in the ABI Prism 3100 DNA Sequencer (Applied Biosystems). The sequences obtained were analysed using the program PREGAP and GAP4 from the STADEN package 10.0. Only nucleotide sequences with a phred value higher than 20 were considered for analysis.

GenoType MTBDR assay - The RHA results from 24 DNA samples extracted from cultures of $M$. tuberculosis ( 15 with the mutation $\mathrm{ACC}$ in $k a t \mathrm{G} 315,8$ with no mutation in this codon and 1 isolate with the mix AGC/ACC) were compared with the results of the GenoType MTBDR assay (Hain Lifescience, Nehren, Germany). These sam- ples were submitted to GenoType MTBDR, a commercial molecular test based on reverse hybridisation for the determination of mutations associated with susceptibility or resistance to RIF and INH. Experimental conditions were set up according to the manufacturer's instructions.

PCR primers and hybridisation probes - Primers katG1 and katG2 (biotinylated) were used to generate a $232 \mathrm{bp}$ fragment of $k a t \mathrm{G}$. A $245 \mathrm{bp}$ fragment of the insertion element IS6110 (IS) (used to confirm the presence of the M. tuberculosis complex) was amplified using primers INS1 (BIO-CGTGAGGGCATCGAGGTGGC) and INS2 (BIO-GCGTAGGCGTCGGTGACAAA), described by Hermans et al. (1990).

The oligonucleotide probes were designed using the Primer Express Software v2.0 (Applied Biosystems) and included a wild-type probe (1W) (AMN-TCACCAGCGGCATCGAG) and a mutated probe (2M) (AMN-TCACCACCGGCATCGAG) for detection of the kat $\mathrm{G} 315$ mutation ACC. The probe for IS (AMN-TTTTTTTTTTGCCCGTCCCGCCGATCTC) was designed to be complementary to an internal sequence of insertion element IS. These probes were manufactured by Invitrogen with the 5'-terminal amino group.

Amplification conditions - The $k a t \mathrm{G}$ and IS fragments were generated in a single PCR reaction of $50 \mu \mathrm{L}$ containing $200 \mu \mathrm{M}$ of each dNTP, $10 \mathrm{mM}$ Tris- $\mathrm{HCl}$ (pH 8), 50

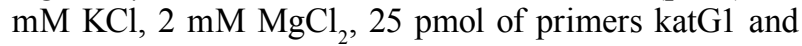
katG2, 10 pmol of primers INS1 and INS2, 2.5 units of Taq DNA Polymerase (Cenbiot/UFRGS, Brazil) and $100 \mathrm{ng}$ of genomic DNA. The amplification reactions were carried out in a Mini-Cycler-Hot Bonnet PTC-150 thermocycler (MJ Research) as follows: $95^{\circ} \mathrm{C}$ for $3 \mathrm{~min} ; 35$ cycles of $95^{\circ} \mathrm{C}$ for $1 \mathrm{~min}, 60^{\circ} \mathrm{C}$ for $1 \mathrm{~min}, 72^{\circ} \mathrm{C}$ for $1.5 \mathrm{~min}$ and $72^{\circ} \mathrm{C}$ for $4 \mathrm{~min}$. Each experiment included a negative (water instead of template DNA) and a positive control (M. tuberculosis H37Rv DNA, $100 \mathrm{ng}$ ). The PCR products were analysed by electrophoresis in a $10 \%$ polyacrylamide gel.

Immobilisation of probes on the membrane - Four circles of $5 \mathrm{~mm}$ in diameter were drawn on a negativelycharged nylon membrane (Biodyne C, Pall Corporation), which was cut into $1.5 \mathrm{~cm} \times 2 \mathrm{~cm}$ pieces. The membrane pieces were then activated in a freshly prepared solution of 16\% EDAC [1-(3-dimethylaminopropyl)-3-ethylcarbodiimide hydrochloride, Acros Organics] for $15 \mathrm{~min}$ at room temperature (RT) and were washed in distilled water for $2 \mathrm{~min}$ at RT. Next, $10 \mu \mathrm{L}$ of the 5'-aminated oligonucleotide probes $1 \mathrm{~W}(0.02 \mathrm{pmol} / \mu \mathrm{L}), 2 \mathrm{M}(0.1 \mathrm{pmol} / \mu \mathrm{L})$ and IS $(1.15 \mathrm{pmol} / \mu \mathrm{L})$ in $0.5 \mathrm{M} \mathrm{NaHCO}_{3}(\mathrm{pH} 8.4)$ and the conjugate control (CC) $(0.01 \mu \mathrm{g} / \mu \mathrm{L}$ of streptavidinalkaline phosphatase conjugate, Invitrogen) were spotted separately in each of the four circles and incubated for $1 \mathrm{~min}$ at RT. The membranes were then incubated in $0.1 \mathrm{M} \mathrm{NaOH}$ for $10 \mathrm{~min}$ at RT and rinsed first with distilled water for $2 \mathrm{~min}$ at RT, second with $2 \mathrm{X} \mathrm{SSC} / 0.1 \%$ SDS (sodium chloride-sodium citrate buffer/sodium dodecyl sulfate) for $10 \mathrm{~min}$ at $50^{\circ} \mathrm{C}$ and finally with $20 \mathrm{mM}$ EDTA ( $\mathrm{pH}$ 8.0) for $15 \mathrm{~min}$ at RT. Membranes were then sealed and stored at $4^{\circ} \mathrm{C}$ until further use. 
Hybridisation and colorimetric detection of biotinylated PCR products - Before hybridisation, membranes were rinsed with $2 \mathrm{X} \mathrm{SSC} / 0.1 \% \mathrm{SDS}$ for $5 \mathrm{~min}$ at $50^{\circ} \mathrm{C}$ and blocked by incubating in $2 \mathrm{X} \mathrm{SSC}$ with $3 \%$ bovine serum albumin (BSA, Inlab) at $50^{\circ} \mathrm{C}$ for $15 \mathrm{~min}$. Twenty microlitres of biotinylated PCR products were diluted in $150 \mu \mathrm{L}$ of $2 \mathrm{X} \mathrm{SSC} / 0.1 \% \mathrm{SDS}$, denatured at $100^{\circ} \mathrm{C}$ for $10 \mathrm{~min}$, transferred to $4{ }^{\circ} \mathrm{C}$ and incubated with the membranes in $2 \mathrm{X} \mathrm{SSC} / 0.1 \% \mathrm{SDS}$ at $62^{\circ} \mathrm{C}$ for $45 \mathrm{~min}$. After hybridisation, the excess PCR products were removed. The membranes was consecutively washed twice with $2 \times \mathrm{SSC} / 0.5 \% \mathrm{SDS}$ and $0.2 \times \mathrm{SSC} / 0.5 \% \mathrm{SDS}$ at $57^{\circ} \mathrm{C}$ for $10 \mathrm{~min}$, incubated in TSB buffer $(100 \mathrm{mM}$ Tris- $\mathrm{HCl}$, $150 \mathrm{mM} \mathrm{NaCl}, \mathrm{pH} 7.5$ ) containing $6 \%$ BSA for $30 \mathrm{~min}$ at $50^{\circ} \mathrm{C}$ and in TSB buffer for $5 \mathrm{~min}$ at RT. The membranes were then incubated in TSB buffer containing $0.33 \mu \mathrm{g} / \mathrm{mL}$ streptavidin-alkaline phosphatase conjugate for $15 \mathrm{~min}$ at RT. Excess conjugate was removed by washing in TSB buffer for $10 \mathrm{~min}$ at RT and in TSA buffer $(100 \mathrm{mM}$ Tris- $\mathrm{HCl}, 150 \mathrm{mM} \mathrm{NaCl}$ and $5 \mathrm{mM}$ $\mathrm{MgCl} \cdot 6 \mathrm{H} 2 \mathrm{O}, \mathrm{pH}$ 9.5) for $10 \mathrm{~min}$ at $\mathrm{RT}$. Visualisation of hybridised amplicons was achieved through incubation with TSA buffer containing $40 \mu \mathrm{g} / \mathrm{mL} 5$ - bromo4-chloro-3-indoyl phosphate and $82.5 \mu \mathrm{g} / \mathrm{mL}$ nitro blue tetrazolium (BCIP/NBT, Sigma) for $10 \mathrm{~min}$ at RT. The colorimetric revelation reaction was stopped with distilled water. The membranes were then dried at RT and photographed. The intensity of the hybridisation signals was compared with that obtained from the positive and negative PCR controls.
A

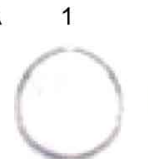

3
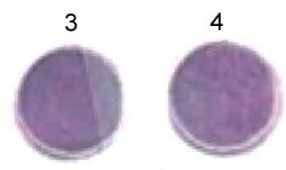

C

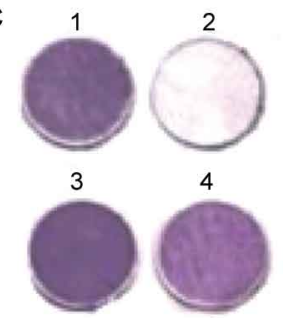

B

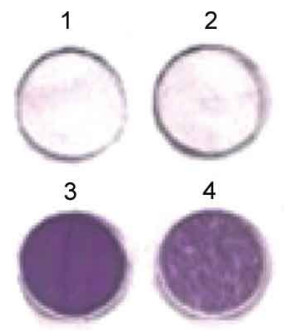

$\mathrm{D}$

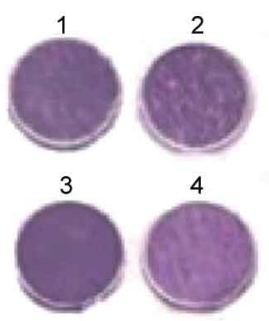

Representative results of the reverse hybridization assay. A: hybridization of the PCR products from samples with the mutation ACC at kat $\mathrm{G} 315$ to the probes; B: hybridization of the PCR products from samples with mutation other than $\mathrm{ACC}$ at katG315 to the probes; $\mathrm{C}$ : hybridization of the PCR products from samples without mutation at kat $\mathrm{G} 315$ to the probes; D: hybridization of the PCR products from samples with the mix AGC/ACC at katG315 to the probes; 1: wildtype probe; 2: mutated probe; 3: IS6110 probe; 4: conjugate control.
Sensitivity and specificity tests - The analytical sensitivity of the RHA was determined by performing the procedure described above using PCR products obtained from a serial dilution of $M$. tuberculosis $\mathrm{H} 37 \mathrm{Rv}$ DNA $(1 \mathrm{pg}$ to $100 \mathrm{ng})$. The specificity of the procedure was determined by performing the described PCR and hybridisation procedure using $100 \mathrm{ng}$ of DNA extracted from Neisseria meningitidis, Pneumococcus pneumoniae, Salmonella enterica and Haemophilus influenzae obtained from the Laboratório Central do Rio Grande do Sul and Mycobacterium marinum, Mycobacterium intracellulare, Mycobacterium scrofulaceum, Mycobacterium gordonae, Mycobacterium avium, Mycobacterium smegmatis, Mycobacterium kansasii, Mycobacterium xenopi, Mycobacterium fortuitum-peregrinum and Mycobacterium phlei obtained from the Instituto Oswaldo Cruz-Fiocruz, Brazil.

Statistical analysis - Statistical analysis was performed using the SPSS 12.0 statistical program (SPSS Ins. Chicago, IL, USA). Agreement between the RHA and DNA sequencing techniques was evaluated using the kappa score.

\section{RESULTS}

The RHA was standardised for detection of the katG315 mutation in DNA from M. tuberculosis. For this purpose, amplification products with the expected sizes of $245 \mathrm{bp}$ (IS) and $232 \mathrm{bp}(\mathrm{kat} \mathrm{G})$ were hybridised to the membrane.

All 58 samples with the mutation ACC in kat $\mathrm{G} 315$ hybridised correctly with the $2 \mathrm{M}$. The positive result was visualised by a purple precipitate on the membrane's spot. The spot of the $1 \mathrm{~W}$ appeared clear, while the spot of the IS probe and $\mathrm{CC}$ were visualised as purple precipitates (A in Figure). Two samples with the mutation AAC in kat $\mathrm{G} 315$ did not hybridise with $1 \mathrm{~W}$ and $2 \mathrm{M}$ probes, but hybridised with the IS probe and reacted with the CC (B in Figure). All 119 samples with no mutation in kat $\mathrm{G} 315$ hybridised correctly with the $1 \mathrm{~W}$ probe. The $2 \mathrm{M}$ spot appeared clear, while the spots of IS and CC were visualised as purple precipitates. The same results were obtained with the reference strain H37Rv (C in Figure). One sample containing both wild-type and mutated DNA sequences (AGC/ACC) in kat $\mathrm{G} 315$ hybridised with both the $1 \mathrm{~W}$ and $2 \mathrm{M}$ probes (D in Figure). The negative PCR control did not hybridize with $1 \mathrm{~W}, 2 \mathrm{M}$ and IS probes. Complete concordance was found with the sequencing results.

The RHA results of 24 of the 180 samples, which displayed complete concordance with the sequencing results, were compared with the results of the GenoType MTBDR assay. This assay could not identify four of the 24 samples; three of them (with the ACC mutation) did not hybridise with the $2 \mathrm{M}$ and reacted with only the $\mathrm{CC}$ and one sample hybridised only with the $1 \mathrm{~W}$ despite the fact that it contained a $75 / 25 \%$ mixture of wild-type and mutated DNA sequences (AGC/ACC) in kat $\mathrm{G} 315$, respectively.

Hybridisation of the amplicons from serial dilutions of $M$. tuberculosis $\mathrm{H} 37 \mathrm{Rv}$ showed that the sensitivity of the method was $10 \mathrm{pg}$. The PCR products from $N$. 
meningitidis, $P$. pneumoniae, S. enterica, H. influenzae, M. marinum, M. intracellulare, M. scrofulaceum, M. gordonae, M. avium, M. smegmatis, M. kansasii, $M$. xenopi, M. fortuitum-peregrinum and M. phlei did not hybridise with any probe.

\section{DISCUSSION}

The early identification of drug resistance would help not only to optimise the treatment of MDR-TB, but also to break chains of transmission, to identify any hot-spot regions in the country for proper implementation of TB control programs (Suresh et al. 2007) and to contribute to the reduction of the cost of total treatment (Jiao et al. 2007).

Mutations in katG315 are associated with a higher minimum inhibitory concentration for INH than mutations in the inhA promoter region and therefore are probably of greater clinical significance (van Soolingen et al. 2000, Ramaswamy et al. 2003, van Doorn et al. 2006). This mutation is associated with viable and virulent pathogens (Heym \& Cole 1992, Mdluli et al. 1998). A possible relationship between the mutation of kat $\mathrm{G} 315$ and transmissibility was suggested in previous reports, in which patients infected with strains containing this mutation were associated with an increased transmission risk (or an increased progression from infection to disease) (van Soolingen et al. 2000, van Doorn et al. 2006). Part of the success of the kat $\mathrm{G} 315$ mutation is probably due to the fact that catalase peroxidase is still active in these mutants (van Doorn et al. 2006). Recently, a study by Dalla Costa et al. (2009) characterised mutations in the $k a t \mathrm{G}, a h p \mathrm{C}$ and $i n h \mathrm{~A}$ gene loci in $224 \mathrm{INH}-$ resistant M. tuberculosis strains from three South American countries, including Brazil. Mutations in $k a t \mathrm{G}$ were observed in $181(80.8 \%)$ of the isolates and, of those mutations, $178(98.3 \%)$ were the $k a t G 315$ mutation $\mathrm{AGC} \rightarrow \mathrm{ACC} /$ $\mathrm{Ser} \rightarrow \mathrm{Thr}$. The data from this study suggest that genetic screening for this mutation may provide rapid information for the selection of an anti-TB regimen, the epidemiological monitoring of INH resistance and, possibly, the tracking of the transmission of INH-resistant strains. These observations indicate that the kat $\mathrm{G} 315$ mutation is an interesting target for diagnostics and further research.

The results obtained in this study using the RHA were very satisfactory. The test could successfully characterise the kat $\mathrm{G} 315$ mutation in $100 \%$ of DNA samples from M. tuberculosis as compared to DNA sequencing. The assay also showed high analytical sensitivity and specificity. The RHA, when compared to the GenoType MTBDR assay, showed greater accuracy in detecting the mix AGC/ACC.

The RHA could be an accurate and sensitive tool for the rapid identification of INH-resistant $M$. tuberculosis associated with the kat $\mathrm{G} 315$ mutation. The test requires simple equipment, is inexpensive and the results are easily interpretable. The test also reveals the presence of additional mutations besides ACC in kat $\mathrm{G} 315$ by a negative hybridisation result with the $1 \mathrm{~W}$.

This type of test may be particularly important for some geographical locations/ethnic groups where $M$. $t u$ berculosis strains with the mutation ACC in the katG315 gene occur more frequently. It will also be helpful in locations with a low prevalence of these mutations because, by adjusting treatment regimens, the emergence of MDR-TB strains can be controlled. This control is important since MDR-TB strains are more likely to acquire additional resistance (van Soolingen et al. 2000). In addition, resistance surveillance gives a good measure of the efficacy of regional control programmes; molecular epidemiological studies based on the dot-blot method could determine the frequency of specific mutations in a geographical area and monitor the spread of a cluster of drug resistant strains within a community or institution (Victor et al. 1999). It needs to be mentioned that the use of primers INS1 and INS2 for the identification of isolates of the M. tuberculosis complex could lead to false positive results in laboratories that perform fingerprinting by IS-RFLP. Therefore, the RHA was done with all the necessary precautions to avoid this contamination. The design of primers that amplify another sequence such as 16S-23S rRNA is underway.

As of yet, molecular genetic testing cannot fully replace conventional phenotypic susceptibility testing, but this test might be a good alternative for a drug resistance screening of kat $\mathrm{G} 315$ in the context of an MDR DOTSplus strategy (van Rie et al. 2001).

\section{REFERENCES}

Abate G, Hoffner SE, Thomsen VO, Miorner H 2001. Characterization of isoniazid-resistant strains of Mycobacterium tuberculosis on the basis of phenotypic properties and mutations in katG. Eur J Clin Microbiol Infect Dis 20: 329-333.

Dalla Costa ER, Ribeiro MO, Silva MSN, Arnold LS, Rostirolla DC, Cafrune PI, Espinoza RC, Palaci M, Telles MA, Ritacco V, Suffys PN, Lopes ML, Campelo CL, Miranda SS, Kremer K, Silva PEA, Fonseca LS, Ho JL, Kritski AL, Rossetti MLR 2009. Correlations of mutations in kat $\mathrm{G}$, oxy $\mathrm{R}-a h p \mathrm{C}$ and inh $\mathrm{A}$ genes and in vitro susceptibility in Mycobacterium tuberculosis clinical strains segregated by spoligotype families from tuberculosis prevalent countries in South America. BMC Microbiol 9: 39.

Espinal MA, Laszlo A, Simonsen L, Boulahbal F, Kim, SJ, Reniero A, Hoffner S, Rieder HL, Binkin N, Dye C, Williams R, Raviglione MC 2001. Global trends in resistance to antituberculosis drugs. N Engl J Med 344: 1294-1303.

Hazbon MH, Brimacombe M, Bobadilla del Valle M, Cavatore M, Guerrero MI, Varma-Basil M, Billman-Jacobe H, Lavender C, Fyfe J, Garcia-Garcia L, Leon CI, Bose M, Chaves F, Murray M, Eisenach KD, Sifuentes-Osornio J, Cave MD, Ponce de Leon A, Alland D 2006. Population genetics study of isoniazid resistance mutations and evolution of multidrug-resistant Mycobacterium tuberculosis. Antimicrob Agents Chemother 50: 2640-2649.

Hermans PWM, Soolingen DV, Dale JW Schuitema ARJ, Mcadam RA, Catty D, Van Embden JDA 1990. Insertion element IS986 from Mycobacterium tuberculosis: a useful tool for diagnosis and epidemiology of tuberculosis. J Clin Microbiol 28: 2051-2058.

Heym B, Cole ST 1992. Isolation and characterization of isoniazidresistant mutants of Mycobacterium smegmatis and M. aurum. Res Microbiol 143: 721-730.

Hillemann D, Kubica T, Agzamova R, Venera B, Rusch-Gerdes S, Niemann S 2005. Rifampicin and isoniazid resistance mutations in Mycobacterium tuberculosis strains isolated from patients in Kazakhstan. Int J Tuberc Lung Dis 9: 1161-1167. 
Jiao WW, Mokrousov I, Sun GZ, Li M, Liu JW, Narvskaya O, Shen, AD 2007. Molecular characteristics of rifampin and isoniazid resistant Mycobacterium tuberculosis strains from Beijing, China. Chin Med J (Engl) 120: 814-819.

Kapetanaki SM, Chouchane S, Yu S, Zhao X, Magliozzo RS, Schelvis JP 2005. Mycobacterium tuberculosis Kat G (S315T) catalaseperoxidase retains all active site properties for proper catalytic function. Biochemistry 44: 243-252.

Makinen J, Marttila HJ, Marjamaki M, Viljanen MK, Soini H 2006. Comparison of two commercially available DNA line probe assays for detection of multidrug-resistant Mycobacterium tuberculosis. J Clin Microbiol 44: 350-352.

Mdluli K, Sherman DR, Hickey MJ 1996. Biochemical and genetic data suggest that inh $\mathrm{A}$ is not the primary target for activated isoniazid in Mycobacterium tuberculosis. J Infect Dis 174: 1085-1090.

Mdluli K, Slayden RA, Zhu Y, Ramaswamy S, Pan X, Mead D, Crane DD, Musser JM, Barry III CE 1998. Inhibition of a Mycobacterium tuberculosis beta-ketoacyl ACP synthase by isoniazid. Science 280: 1607-1610.

Mokrousov I, Narvskaya O, Otten T, Limeschenko E, Steklova L, Vyshnevskiy B 2002. High prevalence of KatG Ser315Thr substitution among isoniazid-resistant Mycobacterium tuberculosis clinical isolates from Northwestern Russia, 1996 to 2001. Antimicrob Agents Chemother 46: 1417-1424.

Musser JM, Kapur V, Williams DL, Kreiswirth BN, van Soolingen D, van Embden JD 1996. Characterization of the catalase-peroxidase gene $(k a t \mathrm{G})$ and $i n h \mathrm{~A}$ locus in isoniazid-resistant and -susceptible strains of Mycobacterium tuberculosis by automated DNA sequencing: restricted array of mutations associated with drug resistance. J Infect Dis 173: 196-202.

Parsons LM, Somoskovi A, Urbanczik R, Salfingerm M 2004. Laboratory diagnostic aspects of drug resistant tuberculosis. Front Biosci 9: 2086-2105.

Pym AS, Saint-Joanis B, Cole ST 2002. Effect of katG mutations on the virulence of Mycobacterium tuberculosis and the implication for transmission in humans. Infect Immun 70: 4955-4960.

Ramaswamy SV, Reich R, Dou SJ, Jasperse L, Pan X, Wanger A, Quitugua T, Graviss EA 2003. Single nucleotide polymorphisms in genes associated with isoniazid resistance in Mycobacterium tuberculosis. Antimicrob Agents Chemother 47: 1241-1250.

Rawat R, Whitty A, Tonge PJ 2003. The isoniazid-NAD adduct is a slow, tight-binding inhibitor of InhA, the Mycobacterium tuberculosis enoyl reductase: adduct affinity and drug resistance. Proc Natl Acad Sci USA 100: 13881-13886.

Saint-Joanis B, Souchon H, Wilming M, Johnsson K, Alzari PM, Cole ST 1999. Use of site-directed mutagenesis to probe the structure, function and isoniazid activation of the catalase/peroxidase, $K a t \mathrm{G}$, from Mycobacterium tuberculosis. Biochem J 338: 753-760.

Silva MS, Senna SG, Ribeiro MO, Valim AR, Telles MA, Kritski A, Morlock GP, Cooksey RC, Zaha A, Rossetti ML 2003. Mutations in $k a t \mathrm{G}$, inh $\mathrm{A}$ and $\operatorname{ahpC}$ genes of Brazilian isoniazid-resis- tant isolates of Mycobacterium tuberculosis. J Clin Microbiol 41: 4471-4474

Suresh N, Singh UB, Gupta C, Arora J, Rana T, Samantaray JC 2007. Rapid detection of rifampin-resistant Mycobacterium tuberculosis directly from stained sputum smears using single-tube nested polymerase chain reaction deoxyribonucleic acid sequencing. Diagn Microbiol Infect Dis 58: 217-222.

van Doorn HR, De Haas PE, Kremer K, Vandenbroucke-Grauls CM, Borgdorff MW, van Soolingen D 2006. Public health impact of isoniazid-resistant Mycobacterium tuberculosis strains with a mutation at amino-acid position 315 of kat $\mathrm{G}$ : a decade of experience in The Netherlands. Clin Microbiol Infect 12: 769-775.

van Doorn HR, Kuijper EJ, van der Ende A, Welten AG, van Soolingen D, de Haas PE, Dankert J 2001. The susceptibility of Mycobacterium tuberculosis to isoniazid and the Arg-Leu mutation at codon 463 of $k a t \mathrm{G}$ are not associated. J Clin Microbiol 39: 1591-1594.

van Rie A, Warren R, Mshanga I, Jordaan AM, van der Spuy GD, Richardson M, Simpson J, Gie RP, Enarson DA, Beyers N, van Helden PD, Victor TC 2001. Analysis for a limited number of gene codons can predict drug resistance of Mycobacterium tuberculosis in a high-incidence community. J Clin Microbiol 39: 636-641.

van Soolingen D, De Hass PE, Hermans PWM, Van Embden JDA 1994. DNA Fingerprinting of Mycobacterium tuberculosis. Methods Enzymol 235: 196-204.

van Soolingen D, De Haas PE, van Doorn HR, Kuijper E, Rinder H, Borgdorff MW 2000. Mutations at amino acid position 315 of the $k a t \mathrm{G}$ gene are associated with high-level resistance to isoniazid, other drug resistance and successful transmission of Mycobacterium tuberculosis in the Netherlands. J Infect Dis 182: 1788-1790.

Victor TC, Jordaan AM, van Rie A, van der Spuy GD, Richardson M, van Helden PD, Warren R 1999. Detection of mutations in drug resistance genes of Mycobacterium tuberculosis by a dot-blot hybridization strategy. Tuber Lung Dis 79: 343-348.

Wei CJ, Lei B, Musser JM, Tu SC 2003. Isoniazid activation defects in recombinant Mycobacterium tuberculosis catalase-peroxidase $(K a t \mathrm{G})$ mutants evident in InhA inhibitor production. Antimicrob Agents Chemother 47: 670-675.

WHO - World Health Organization 2008. Global tuberculosis control: surveillance, planning, financing. WHO/HTM/TB/2008.393. Available from: http://www.who.int/tb/publications/global_report/2008/pdf/fullreport.pdf.

Zakerbostanabad S, Titov LP, Bahrmand AR 2008. Frequency and molecular characterization of isoniazid resistance in kat $\mathrm{G}$ region of MDR isolates from tuberculosis patients in southern endemic border of Iran. Infect Genet Evol 8: 15-19.

Zhang M, Yue J, Yang YP, Zhang HM, Lei, JQ, Jin RL, Zhang XL, Wang HH 2005. Detection of mutations associated with isoniazid resistance in Mycobacterium tuberculosis isolates from China. J Clin Microbiol 43: 5477-5482.

Zumla A, Grange JM 2001. Multidrug-resistant tuberculosis - can the tide be turned? Lancet Infect Dis 1: 199-202. 